\title{
In pursuit of the heritage and place synergy: the environmental impact of Panemunè Castle as a heritage property and entirety of values. A study
}

\author{
Vaida Ščigliene் $\dot{1}^{1}$ Vaida Almonaitytė-Navickiene் $\dot{e}^{2}$ \\ Kristina Daubaryte் ${ }^{2}$, Ieva Kuiziniene் ${ }^{1}$, Angelė Čepẻnaite் ${ }^{1}$
}

\author{
${ }^{1}$ UNESCO Culture Management and Cultural Policy Department, Vilnius Academy of Arts, \\ e-mail:vaida.scigliene@vda.lt,ieva.kuiziniene@vda.lt,cepangele@gmail.com \\ ${ }^{2}$ Department of Humanities of Kaunas Faculty, Vilnius Academy of Arts, \\ e-mail:vaida.navickiene@vda.lt,kristina.daubaryte@vda.lt
}

\begin{abstract}
The study on Panemunè Castle examined this heritage object in an entirety of its values and their impact on the environment, with a possibility of their synergism for the benefit of the place. It found the contemporary national heritage protection framework failing to grant equal attention to elements constituting the multifaceted worth of the castle as a property, inclusive of the social, cultural, artistic values, the engagement of local communities, the important role of cultural tourism and the image of the place, and economic efficiency. The analysis of the different facets one by one and collectively has brought to the conclusion that the social, cultural, artistic and economic values of Panemune Castle as a heritage property influence their environment, but are not experienced as a powerful driving force of the contemporary heritage protection. The process remains fragmented, sporadic and underdeveloped, with its elements failing to achieve synergism for the place.

Keywords: utilisation, inclusive society, heritage community, the impact of sociocultural and artistic activities on a heritage property, opportunities of branding a cultural heritage property; potential, the criteria of cultural heritage assessment: cultural, social, economic values.
\end{abstract}

\section{Introduction}

Panemune Castle seems to be a case of the Lithuanian heritage preservation when a property receives adequate management and is in use. The heritage property belongs to Vilnius Academy of Arts (VAA henceforth), the institution of higher education, actively involved in the processes of the Lithuanian cultural policy. It takes care to ensure physical safeguarding of the castle, the renovation work; the Academy gives a thought about strategies for the future, too. The castle stands out within the context of the Lithuanian architectural heritage through its authenticity, significance and rarity: they should be credited for attracting visitors willing to tour the place. Panemune Castle is part of a large group of heritage objects concentrated in a scenic district of Jurbarkas. The development and enhancement of cultural tourism potential of this constellation of heritage is on the regional agenda and in the focus of the national cultural tourism sector. The location of the castle in a rural settlement adds unique features to the property and enables its local community to enjoy and use it in their daily life. Even though this background knowledge on Panemune 
Castle seems to cast its situation in a positive light, a thorough examination of it as a cultural heritage asset brings forth problems endemic to the very framework of the local and the national heritage protection practice.

The case of Panemune Castle has been analysed in terms of its present day operations and its context, inclusive of its immediate location, of social, cultural and artistic setting. Do these aspects constitute the values of it as a cultural heritage object? Do they contribute to the reanimation of this heritage? What are the possible directions of the management and further (re)animation of the place?

The study approaches Panemunè Castle as an entirety of values. Our research has embraced key and but all facets of the cultural heritage object: its social, cultural and artistic significance, the impact of local communities, the significance of cultural tourism, the role of the image and the economic efficiency. The research aspired to demonstrate that the entirety of values is capable of considerable influence on the environment, may succeed or fail to produce synergy for the place. The need to consider the entirety of values attributed to heritage deserves adequate attention as a powerful driving force of the contemporary heritage protection effort.

The analysis of Panemune Castle was guided by the following goals:

1. To identify and to analyse how the heritage property is adapted to public needs and expectations, and to those of its local community, as well as to the broader social and economic needs;

2. To investigate the nature of the impact of Panemune Castle, as a heritage property, on regional development;

3. To identify and systematize the opportunities, problems and ways to employ the image of Panemunè Castle as a cultural heritage;

4. To conduct qualitative research, field research, interviews with key stakeholders of Panemune Castle, to examine and to analyse the research-produced data;

5. To employ the results by the study in shaping out proposals towards enhancing transparency and universality of the assessment criteria applied for cultural heritage.

The study and assessment of the cultural heritage, the listing of properties and the implementation of safeguarding and usage strategies should avoid perceiving heritage objects as isolated and belonging to the past and history. We want to approach the heritage rather as a contemporary process that subsumes the elements of political, social, artistic activities and initiatives in and around it. The ideas about cultural heritage must be organized on multiple axes and embrace the dimensions of past, present and the future. The anthropologic concept of culture and its heritage, and of the heritage as a past and present cultural and economic asset emerge in the international documents such, as for instance, The Framework Convention on the Value of Cultural Heritage for Society [1] (henceforth, the Faro Convention). Cultural heritage has a role to play in the quotidian life and is capable of lending this life a strong foundation and continuity locally. Such contemporary researchers of the cultural heritage as Milena Dragićević-Šešić [2], Laurajane Smith [3], David C. Harvey [4], to mention just some of them, perceive heritage as a continuous process. "Heritage" these days is rather a verb than a noun, and the emphasis is on the process instead of the final product. When we bring Panemune Castle into the highlight with an agenda to represent it as an opportunity to enhance the fulfilment of cultural, economic and social needs, we want to be guided by a thorough appreciation of the forms of cultural heritage and of their manifestations emerging from interactions of a variety of practices. The contemporary heritage preservation policy and practices are especially alert to the importance and value of inclusive society and to the factor of community participation in 
the heritage-related processes. Since individual human links represent the most sensitive area in connection to the heritage, they are bound to generate most unknowns. The relation of local citizenry to heritage is changing: and the change may be caused by a diversity of factors (or a number of them collectively): new owners of a heritage property, a new status, new activities taking place in and around, and last, but not the least, even a changed appearance. The process of designation and listing does not translate overnight into a new social structure capable of animating the heritage property in spite of the state safeguarding effort. Each community creates its own space with its idiosyncratic qualities and a character, so there is always a risk that the changes made to the heritage property may probably harm or destroy the already existing space. On the other hand, such changes have also the potential to inspire and trigger new communities to shape and emerge. Given the possibility of both avenues, we come up with a natural question about the causes behind the shaping or breaking of heritage communities. The analysis and research into this specific heritage object helped to identify such existing causes and clarify some practical discrepancies.

A variety of scholarly researches into cultural heritage ${ }^{1}$ provides plausible arguments that investment into the cultural heritage stimulates regional growth by contributing to the creation of workplaces, by expanding the range of activities and by increasing investment attraction. Contemporary society tends to prioritize the economic value of the heritage as it expects to benefit from investments into culture, in the form of the life quality improvement and the economic growth in general. The economic effect is boosted and catalysed by the image of a given heritage property which triggers and sustains cultural tourism at the starting and during established phase, contributing to its further intensity. The image and cultural tourism are two sides of the same coin, complementing and stimulating each other. In Lithuania, however, only in ideal cases we see the efforts of image shaping and proliferation towards a higher effectiveness and profitability of cultural tourism.

Over the course of research, rich scholar resources have been consulted on respective aspects within the paper's thematic scope, inclusive of the general relevant coeval theoretical research and the studies of the cultural heritage protection and culture as well as the diversity of practices, the international acts and regulations. The field research and the firsthand information collected by the team has significantly contributed to the quality of the study. Visits were paid ${ }^{2}$ to Panemune Castle, to the municipality of Jurbarkas district (the subdivisions of heritage protection and ethnic culture under the division of culture), to the tourism and information centre of Jurbarkas, A. Sodeika Art School in Jurbarkas. During these visits, the researchers interacted and discussed with people whose life directly connects to Panemune Castle ${ }^{3}$. Real stories and memories was the most relevant source for the assessment of community dimension, the routinely held meetings with the local community members provided for an obvious evidence of changes either taking place, or failing to do so. The analysis of this dynamics was integrated into the study.

\section{Social, cultural and artistic environment and its value}

An overview of the values attributed to the national level heritage property by the methodology of the Register of Cultural Properties of Lithuania ${ }^{4}$, makes it clear that the Lithuanian heritization practice is dominated by a single axis assessment system and the gravity centre is set on the cultural and historical value of heritage. The conservation paradigm dominates the heritage preservation effort wherein significance of a property is established largely by the criteria of artistic qualities and authenticity, leaving out the social and economic values. These are expected to resurface naturally or are left for the future to take care of. This study has sought to investigate and to demonstrate that the factoring in 
the economic and sociocultural processes is important not only to the heritage properties as such and to their mundane environment (which keeps shaping them), but is equally of consequence to the processes of heritization and the assessment of properties.

\subsection{The values of the national cultural heritage property attributed through the process of listing}

The goal of conducting a thorough study of Panemune Castle as a heritage property with the entirety of its values called for a review of the original designation and heritization processes. At this stage, all the background information collected on the cultural heritage property for the purpose of listing is of special relevance.

Panemune Castle, located in Pilies I village, (Skirsnemune ward), in the municipality of Jurbarkas district, was entered into the Register of Cultural Properties of Lithuania in 1992, rated as a property of the national level of significance (unique code 968). Based on its structure, the property represents a complex with an area of $152,456,00 \mathrm{sq} \mathrm{m}$. [5] The identified valuable features are: archaeological, architectural (sets the significance described as "rare"), artistic (sets its significance as "rare"), historical (sets its significance as "important"), landscape and sacral character (sets its significance as "important"), greenery (sets its significance as "rare").

Recounted are the following valuable properties:

1. Structural - the masonry foundation and fieldstone pavement (of the north-western section of the castle courtyard between a northward part of the west wing and a westward part of the north wing);

2. Planning solutions: the plan structure, the volume/space composition inclusive of the castle mansion, the burial chapel, the landscape park with an elaborate chain of ponds, and the lifting equipment of the gullied slope of the Nemunas River;

3. The relics of the former set of buildings or their sites: the site of the former 14 16th C. building (the foundation was unearthed during archaeological excavations), the site of the former gate (the gate of a rectangular plan with buttress support on both sides, built in 1604-1610, demolished in 1786; the brick masonry cellar from the first half of the 20th $\mathrm{C}$.;

4. Land and its surface elements: the gullied slope of the Nemunas River, Eastern Hill, called Kalviniškis Mount; cultural stratum (the layer of dark soil with archaeological finds; in 1955, 1959-1960, 1994 and in 2002, archaeological excavations were conducted in the area of over $600 \mathrm{sq} \mathrm{km}$, a part of the cultural stratum was destroyed in the process of restoration, especially during conversion project of the north wing when an excavator was used to open cellars;

5. Paths, roads and their fragments, and surfaces: the routes of the east, north and south-west roads and of the central road between ponds No. 3 and No. 4 (built in the first half of the 20th C.);

6. Rivers, natural water features and hydro-technical equipment: the channel of the Melnyčupis River at the boundary of the East territory;

7. Authenticity of immediate surrounding environment: the complex is situated in the Panemuniai Regional Park.

The Register of Cultural Properties provides facts on public, cultural and state figures of connected to the property. Archaeological evidence points to the likelihood of the existence of some structures on the site of Panemune Castle back in the $15^{\text {th }} \mathrm{C}$. In the $16^{\text {th }} \mathrm{C}$., the estate belonged to the Samogitian chamberlain Stanislovui Stankevičius-Bielevičius and in 1597, it was bought by Janusz Eperjesh, a nobleman of Hungarian descent. The inventory drawn at the time includes, besides the buildings, gardens, damns, watermills and ponds. 
A residential castle was built in 1604-1610, not as a fortress designed for the defence of the country, but a typical $17^{\text {th }} \mathrm{C}$. - feudal castle that could offer protection from internal unrest. Five generations of the Eperjesh family resided in the castle. In 1753, they sold the property to baron Col. Leo Igolshtrom, the foreman of Gulbinai. In 1759, Antanas Gelgaudas (17921831), then supervisor of Akmene, purchased the estate. He was to lead the 1831 antiRussian uprising. The Gelgaudas family transformed the building into a family manor house, and created a landscape park integrating the former system of ponds. Following the suppression of the uprising, Panemune estate with the castle was sequestrated, it passed over to the Property Ward. This brought a spell of decay for Panemune, when the appointed treasury administrators ran the castle and the estate. In 1867, it passed into the hands of landlord Stanislovas Puslovskis who inherited the Gelgaudas property (and was also called Zamkus estate). The Land reform in the aftermath of the First World War expropriated the estate and its central part was sold to the Lithuanian-American priest Antanas Petraitis (1861-1933) who, in his turn, made a bequest of the property to the Salesians of Don Bosco. The monks built a burial chapel on the hill called Kalviniškis Mount and transferred the relics of their benefactor to the chapel (during the war the relics of the priest were transferred to the crypt of the Church of St George in Skirsnemune). In 1935, Panemune was handed over to the Archaeology Commission of the Ministry of Culture and since then was owned by a variety of cultural and educational institutions. In 1935, the settlement in the vicinity received the name of Vytenai extended to the castle as well.

\subsection{The data establishing the cultural and historical value; the manage- ment of the property and other facts related to its present situation}

Panemunè Castle (Gelgaudų and Vytenu as other names) is one of the few (below twenty) castles extant in Lithuania. It has been partially reconstructed. Panemune is the most authentic structure among the Lithuanian residential castles from the 17th -18 th $\mathrm{C}$. (Gudiene [6]). Abandoned and neglected, and since 1935 handed over to the Ministry of Education: this set of circumstance secured the preservation of its authenticity. Panemune did not have its function altered as it happened with the other properties of tangible heritage, many of which were converted and used as warehouses, public buildings, converted into flats, what in many cases resulted in the destruction of their authenticity.

Panemune is situated in the Regional Panemuniai Park, which is listed in the State Cadastre of Protected Areas. Panemune Castle therefore finds itself under a double protection (of the Law on Protection of Immovable Cultural Heritage and the Law of Protected Areas). Panemunè Castle is situated in the district of Jurbarkas with the largest Lithuanian Nemunas River streching across these lands for $70 \mathrm{~km}$. This is why these lands take the name from the river as "Nemunas Land" or "Panemuniai". In the general plan of Lithuania, it stands out as one of the most important areas for the national history of Lithuania [7]. Panemune Castle is surrounded by a landscape park of 15 ha with five ponds, formerly, with watermills on the four of these. Circa 1783, the grounds were transformed into a Neoclassical style landscape park complete with the resting hills, teahouses, an orangery, and a menagerie for fallow-deer. The menagerie, just as the orangery with the exotic plant species (Aloe arborescens, hyacinths and orange tress), were lost. The white poplar trees still growing on the edges of the ponds is the only extant of the introduced tree species in the park. The park and three castle ponds are listed in the Cadastre of Lithuanian Rivers, Lakes and Ponds. This way the immediate environment profits from the uniqueness and authenticity of the surrounding cultural landscape.

As the property changed hands, the owners of different periods were conducting both, construction, and reconstruction work on the castle, the architecture of which today is a 
blend of the Renaissance ${ }^{5}$, Baroque and the Neo-classical styles. As a cultural heritage property, Panemune is a complex in terms of composition. Besides the castle mansion, other immovable properties are the Neo-classical landscape park with an elaborate system of ponds, the lifting equipment on the gullied slope of the Nemunas River and the burial chapel by the Salesian monks. The castle mansion originally was four winged, three of the wings are extant: its oldest east wing, its south wing that used to be main in the $18^{\text {th }} \mathrm{C}$., and the west wing, currently housing a museum and premises adjusted for educational and commercial/residential function. The south wing, partially reconstructed, is an exhibition venue. The east wing is currently out of use and awaiting restoration. The north wing did not survive, extant are only its cellars, now emptied and restored.

In considering the cultural and historical value of the complex of Panemune Castle, two main periods in the development of this architectural set of structures need a separate treatment. The period prior to 1935 , when a private status of the property was lost (the data is listed in table 1) and since 1935, when Panemune was turned over to the Ministry of Education, and to Vilnius Academy of Arts. These two periods are marked by a different approach of the masters: when owned, all kind of work, whether demolition, construction or alterations were at the discretion of the owners. When it was transferred to the Ministry of Education, later, to the higher education school, subordinated to the ministry, the safeguarding and protection measures were introduced, and the work of maintenance, restoration and upgrading on the complex started (though some problems have also emerged).

Table 1. The period prior to 1935 in the development of the complex of Panemune Castle

\begin{tabular}{lll}
\hline No. & Period, year & Works on the property, alterations \\
\hline 1. & 14th(?)-16th C. & $\begin{array}{l}\text { Foundations of the former building (property of S. Stankevičius- } \\
\text { Bielevičius); }\end{array}$ \\
\hline 2. & $1604-1610$ & The site of the built gate (property of the Eperjesh generations); \\
\hline 3. & $1604-1610$ & $\begin{array}{l}\text { Construction of a residential castle mansion (property of the Eperjesh } \\
\text { generations); }\end{array}$ \\
\hline 4. & $1759-1832$ & $\begin{array}{l}\text { Alterations to the castle mansion, a landscape park created to integrate the } \\
\text { pre-existing system of ponds (the Gelgaudas property); }\end{array}$ \\
\hline 5. & 1832 & $\begin{array}{l}\text { The sequestration of the estate by the Tsarist government started a period of } \\
\text { decay (property of S. Puslovskis); }\end{array}$ \\
\hline 6. & 1925 & $\begin{array}{l}\text { Expropriation of the estate (the Land Reform); the former estate centre sold } \\
\text { to priest A. Petraitis. The priest bequeathed the property to the Salesian } \\
\text { monks. }\end{array}$ \\
\hline 7. & 1937 & $\begin{array}{l}\text { The Salesians had a burial chapel erected on a hill, popularly, Kalviniškis } \\
\text { Hill; (engineer Valaitis). }\end{array}$ \\
\hline 8. & $\begin{array}{l}\text { Panemune Castle was transferred to the Archaeological Commission of the } \\
\text { Ministry of Education. }\end{array}$ \\
\hline
\end{tabular}

A variety of sources reference different stages of conservation and restoration work on the complex of Panemune, in 1939, 1959-1962, 1984 and in 1995-1997. This paper does not cover or analyse the heritage protection type of work, as this aspect has been comprehensively covered by Rasa Butvilaite in her work of 2015 (Butvilaite [8]), providing a consistent overview of different stages and their appraisal. Butvilaite's study throws new light on the fact that at some stages, the holistic unity of the architectural style of the complex was not safeguarded as some styles were given priority over others (no efforts were put to preserve the Neo-classical style elements but, quite the contrary, to destroy). 
This fact had an obvious impact on the course of its existence. It was only in 1961, when Panemune Castle was put on the list of the Lithuanian Architectural Monuments (Gudiene [6]). Since 1982, Panemunè Castle belongs to Vilnius Academy of Arts.

Vilnius Academy of Arts, as the owner of Panemune, has conducted archaeological research and restoration works on the property. The current restoration project goes on in stages using the funds from the EU. The project the Adapting of Panemune Castle for the needs of cultural tourism: the reconstruction of the western and a part of the southern wings of the mansion and the north-western and south-western towers, completed by 2014, was aimed at adapting Panemune castle mansion and its surrounding park for the needs of cultural tourism. With this aim in mind, the western wing was equipped for a hotel and a café. The project Conservation and adaptation of the southern wing of Panemune mansion for public needs of 2015 - 2016 was financed from the European Economic Space and using the Norwegian Financial Mechanism. The aim of the project is conservation and repair work on the southern wing and purchasing of historical interior elements required for the adaptation of some of the spaces. Specific furniture pieces and equipment are also being purchased that will adjust the heritage complex for the disabled visitors. ${ }^{6}$

VAA approaches the situation of the property with a well-organized plan focused on the preservation and restoration of the heritage resource, the cultural activity is also planned in a targeted manner. The retention of authenticity is at the heart of the effort, keeping the reconstruction and modifications to the minimum. The complex preservation work, including research and study, design, conservation, restoration and reconstruction turned out to be a protracted process. It is impacted by both, the political circumstance and the shortage of funds, lending therefore, a sporadic character to all the managerial moves by the Academy: it has to wait for available funding from the purposive programmes, from the European Structural Funds and other sources. Disbursement schemes drive the process of organizing work and influence where the money is being spent. According to the chief restorer of the heritage resource, currently they try to attract resources for the restoration of the property and to distribute works in a manner that is not at discord, but indeed, helps to reveal the historical property (Dèringytė [9], Palšytė [10]). VAA perceives its mission at Panemunè as that of an an epicentre of contemporary art, tasked with the spearheading of avant-garde art and the dissemination of it within the local provincial context. Given the context of the Lithuanian heritage preservation, Panemune rings a positive note in the practice of protection, conservation and restoration of a heritage property. However, several groups of questions arise in connection to this. What are the prospects for the future research and safeguarding, management and use of the heritage resource as well as the guidelines for raising heritage awareness? What is a further impact on communal, cultural, economic processes? Is Panemune heritage set a finite resource inherited from the past? Is it a resource, perhaps, of the contemporary and future culture? How does the heritage property influence the sense of value and priorities in its immediate environment? How can one adapt the ancient forms for new uses? What can they possibly represent?

The analysis of the situation and the heritage resources reveals a trend wherein values attributed to the heritage tend to shift in relation to communal and cultural contexts. While presenting his classical concept of values (which foregrounded the anthropological aspect) Alois Riegl argued for searching of individual solutions, especially regarding communal and cultural contexts. The Lithuanian Cultural heritage policy defines the heritage and the effort of preservation as a major and inherent part of social life, noting also the importance of protecting its cultural values by way of creating the conditions for the development of heritage as a present and future resource [11]. 


\subsection{The stakeholders of Panemunė Castle; their approach and activities}

For the purpose of this study, it was important to define social environment of the property, to identify different parties interested in the utilisation of Panemune Castle and to take stock of social resources of the area. The municipality of Jurbarkas district is predominantly rural: more people live in villages than in towns. The employment rate is low, there is shortage of jobs for both professional and unskilled labour force. Working and retirement age population dominate in the district of Jurbarkas and in the eldership of Skirsnemune, the numbers of children and young adults tend to decrease. The inclusion of the population groups of different age into activities connected with Panemune Castle is an important indicator for this study.

\begin{tabular}{|c|c|c|}
\hline$=0-18$ & $=19-24$ & $=25-29$ \\
\hline$=30-34$ & $=35-39$ & $=40-49$ \\
\hline$=50-54$ & $=55-59$ & $=60-64$ \\
\hline
\end{tabular}

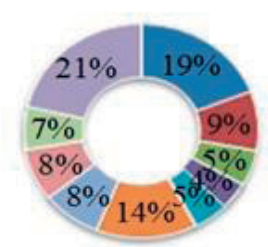

Ill 1. The number of permanent population by age groups in the municipality of Jurbarkas in the beginning of 2016 [12]

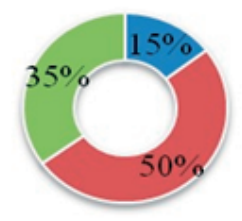

n Children

nopuliation of working age

Retired population

Ill 2. The number of population in the eldership of Skirsnemune, data of 2016 [12]

The current status of Panemune Castle as a heritage property and its condition are complicated not only by protracted restoration and other repair works, its existence is burdened by a poor communication of the interested actors - or the absence of such. We can recount such stakeholders of Panemune: VAA, the owner of the heritage property, the staff of the castle, the local community of Pilies I village, the municipality of the district of Jurbarkas, the tourism and business information centre of Jurbarkas. A hired operator by VAA is a hotel-restaurant Best Baltic Panemunès Pilis which uses the rented premises of the mansion. At this stage, local, regional, Lithuanian and foreign tourists do not figure among these interested parties: their relationship with the property is considered in part III of this study.

The research has revealed that the role of VAA as owner and manager of the heritage property is considered important and is associated with positive future prospects. At the 
same time, the academic community of the school has not arrived at a unanimous solution regarding the character of activity organized at Panemune and has not agreed about the ways of doing it. The relations between the Academy and the academic community with the village people of Pilies I are, in fact, formal, sporadic and unsystematic. The operator Best Baltic Panemunès Pilis is important to the owner in terms of use and profit, yet in dissonance in terms of the managing of public spaces.

According to Regina Kliukiene ${ }^{7}$, specialist of the ethnic culture with the municipality of Jurbarkas the local people cannot picture their area without Panemune Castle. The heritage property attracts visitors, it was viable prior to the restoration and after it. The heritage complex is of cultural significance regionally, the activities organized therein have educational value. When the premises are used for some municipal functions, it is valued mainly as a unique castle setting, ideal for representation, and with available hospitality services. However, the municipal involvement in connection to Panemune Castle is limited to the work of coordinating general tourist routes along the Nemunas.

Panemune Castle plays a significant part in the system of tourist information and travel organization by Jurbarkas tourism and business information centre. The role of the heritage property in the development of a quality cultural tourism services package is well recognized. However, small flows of tourists raise doubts in the effectiveness of the current management of tourism sector in performing its functions.

The population of the village situated next to Panemune Castle are connected to the it not only geographically: they are also linked to its history. Demographic data for the area is not consistent, but based on the statistical data for the past few years, the village totals at over three hundred people. Most of them are of working age or retired, the number of young adults is changing. In 2005, a "Community of Pilies Village" was created with the goal of bringing together those living in Pilies I village for cultural, educational activities and for human interaction. A pilot inquiry into the village community found that the village people are distanced from Panemune Castle. Their events and theme meetings are held at the local community centre; local people seldom take part or go to see the events organized at the castle. One of the reasons for that may be a complicated social portrait of Pilies I village. The village is dying out, even its general education school was closed several years ago. However, a community of the village has features of a strong and active cooperation. They see the castle as playing a part in their life and they try to think of themselves as a castle/heritage community and look for links and possible avenues to collaborate with the owner of the heritage. The Salesians who had enjoyed close historical and cultural links with the place in the first half of the $20 \mathrm{C}$. are now looking for ways to reconnect with it and to give new sense to their presence at Panemunè.

One of the meetings of the community was attended with the goal of finding out more detailed information on the situation. It led to several conclusions: the local community identifies the place with the new owner. Since VAA became an active owner of the property, they tend to feel socially enclosed. Communal links between the staff of Panemune castle, the activities organized, and the neighbouring villagers are fragile. The population of Pilies I village have not yet been engaged in the activity organized at the castle.

After considering the interests entertained by the different actors in regards of this heritage property, it is obvious that though they act in connection to the same property, concerned for its care and usage, there is lack of system and coherence in their approach. The interpretation is divided by disparate interests, compromising the chances for a joint strategy to emerge for the usage of the resource. The efforts to find a common ground between these different actors are insufficient. This leads to the conclusion that different parties act in a disconnected way and lack the principle of unity. 


\subsection{The impact of sociocultural and artistic environment on the heritage object}

As V. Ščiglienè argues based on her previous research ${ }^{8}$ the national strategic documents do recognize that the cultural heritage properties can stimulate society into activity and may influence the economic growth. However, it takes too long for the documents to reflect the changes in the concept of the heritage and the assessment of its properties. No framework exists for the strengthening of communal potential; things tend to happen on an intuitive level, seemingly of their own.

The story of Panemune Castle emerging in this study - starting with the history of its origin and throughout the stages of reconstruction, heritization, and the efforts of utilising makes it obvious how the actual changes in society in regards of cultural heritage have been ignored along the way. The focus has always stayed on the conservation paradigm, no attention has been given to the study of the immediate environment of the property, the harmony and coherence of the different facets of the place (or separate dimensions were considered in disconnection). The intangible heritage and the manifestations of changing human values in this particular cultural region have also been left out of the picture. The efforts are limited on the listed cultural properties: the castle, the park and the chapel, but the context to which they belong receives no due relevance. Next in the paper we attempt to cast this place as a historically inherited accumulation of objects that belong to the administrative, cultural, religious and the quotidian life of the heritage community - as well as a process evolving here and now.

The late $20^{\text {th }} \mathrm{C}$. saw the social value of cultural heritage being brought to the foreground of the heritage picture. The first decades of the $21^{\text {st }} \mathrm{C}$. witnessed an emerging approach to the sphere of cultural heritage as to a history of socialization process. The relevance of the socio-cultural facet selected for the study is underpinned first of all by the international documents broadly used in the world heritage conservation efforts: Council of Europe Framework Convention on the Value of Cultural Heritage for Society [1], Convention on the Protection and Promotion of the Diversity of Cultural Expressions [13], Convention for the Safeguarding of the Intangible Cultural Heritage [14], Québec Declaration On the Preservation of the Spirit of Place [15].

In the case of Panemune Castle, its social value is of importance to the castle as a cultural heritage property. In the light of the concept and theses contained in the Framework Convention on the Value of Cultural Heritage for Society (henceforth, the Faro Convention), Panemunè Castle should evolve in the direction of the strengthening of social cohesion around it, of building closer ties between all of the actors interested in the property. A sustainable development of a variety of activities at and around the castle should also be a priority. The heritage plays a significant role in the everyday life of the people around it; it creates a strong foundation for their life and a hope for continuity, first, locally, and broadens international opportunities. Of great importance in pursuing this goal is the role of the animator of the heritage.

Key definitions used for the purposes of Faro Convention read thus: a) cultural heritage is a group of resources inherited from the past which people identify, independently of ownership, as a reflection and expression of their continuously evolving values, beliefs, knowledge and traditions. It includes all aspects of the environment resulting from the interaction between people and places through time; b) a heritage community consists of people who value specific aspects of cultural heritage which they wish, within the framework of public action, to sustain and transmit to future generations. Of significance are the prepositions in the document which foreground the anthropological concept of culture: 
1. Heritage are resources inherited from the past - heritage as a cultural and economic resource;

2. Everyone has the fundamental right to benefit from the cultural heritage;

3. The way of perceiving cultural capital which implicates the recognition of multifaceted - economic, social, political - potential of the cultural heritage;

4. The role of communities as cultural life without communities is unthinkable.

The UNESCO Convention on the Protection and Promotion of the Diversity of Cultural Expressions is one of the main international legal instruments which is integrated by 140 world countries and the European Union in the foundations of their respective cultural policies. The key principles of the Convention are as follows: support to the sustainable culture management by the states (transparency of cultural policy, mass media, accessibility of digital environment, inclusion of civil society); the promotion of cultural products and services exchange, mobility of artists and culture professionals; the integration of culture into the national sustainable development policies (sustainable distribution of cultural resources to all local communities and vulnerable social groups); respect for the human rights and freedoms within the cultural sector (equity of different cultural spheres, support and accessibility for female artists, free cultural expression, social and economic creator's status). Lithuania ratified the Convention in 2007.

Within a system and structure of heritage preservation, the tangible and intangible heritage is usually closely linked. However, Panemune suffers from a divide between the two, and no linking between the tangible and intangible qualities of the heritage. The manifestations of spiritual heritage, which are prone to change and difficult to trace, have no physical form (though are connected to it), despite of that, it is a significant resource. The most effective method of safeguarding such resources is promoting local cultural action. The intangible heritage is very important because the restoration of a heritage is not limited to a physical reconstruction of an object - it is a revival of a way of life that is and has to be alive. Without a component of the intangible heritage, a tangible property risks to lose its significance, as these two are interdependent.

The complex of Panemune Castle is an agglomeration of tangible and intangible properties. However, the process of identification and heritization/listing, as well as subsequent process of developing a concept for the reconstruction of the buildings, has not included the characteristics of intangible heritage and has not provided for ways to explore their potential. The state policy (the procedure of listing) and the conception by the owner for the restoration of the property is essential targeted at safeguarding and revitalizing of the tangible property, while the intangible qualities are not taken into consideration. The situation of the kind is not exclusive to Panemune when we come to consider the general practice of heritage identification, and especially so, of listing. Therefore the system of assessment of heritage properties needs a better balance between its tangible and intangible elements, a relationship of dialogue, capable of bringing to the fore the significance and value of the heritage object and its immediate environment. It is only through the realization of the intangible properties that a material property is created and vice versa [3]. The potential of intangible heritage (such as local crafts and businesses) is not perceived at Panemune these days as a manifold structure, and is not utilised in a purposeful manner; no clear strategic development system is in place. The activity organized by VAA is concerned only with the tangible property: no adequate value is recognised to the intangible heritage of the place. Yet the intangible property cannot be divided from the tangible object due to their deeply inherent interdependence. In summing up, the cultural heritage is not a finite entity, it depends on the management of the values attributed by human beings. The owner of Panemune has adopted a conservational approach, refusing to explore the potential of 
socio-cultural or economic capital of the property and its potential benefit to all social layers connected to the heritage place.

The study has found that the cultural and artistic activity of VAA, as a higher education institution of professional art, has a very strong impact not only on the immediate environment, on the town of Jurbarkas, but also regionally. However, these activities do not represent any system or direction/s. The academic community of the Academy currently see Panemune as an exhibition venue. After completion of the restoration, there will be space in residential castle dedicated specifically to cultural heritage: a castle museum and a restored historical kitchen; the remainder of the space of the building will be adapted for accommodation function (hotel) and a venue for exhibitions/conferences, showcasing art unconnected to historical resources of the castle.

In connection to projections along what lines the Lithuanian heritage policy may evolve in the future, there is one recommendation we would like to make: to appreciate the links between the intangible and the tangible properties and all forms of values generated by these links. It is also advisable to take note of the changing sensibilities of the contemporary society and the need for sustainable management of the heritage. To develop a continuous dialogue with the disseminators and users of intangible heritage, with investors, planners and other actors who have expectations vested in the property is another goal to pursue. The policy and management of the heritage should embrace not only the dimension of history and traditional culture but also practices imbedded in the contemporary communities and culture, and seek economic and societal impact.

\section{The heritage community}

Open conversations, unconstrained by a structured questionnaire, allowed to measure the attitudes, views and expectations of the people. The method of semantic differential was used in the process: the interlocutors were given 12 dichotomous pairs of questions: valuable - unworthy; unique - typical; national - provincial, communal - state run; authentic falsified; used - useless; visited - not interesting; prospective - having no future; mass exclusive; cosmopolitan - folk; attractive - repulsive; familiar - strange. The method selected led to the conclusion that emotions in connection to the heritage property depend on an individual social and cultural experience. Their perception of the place emerging from the evaluation based on semantic dichotomies reveals general approach to the heritage, some stereotypes and identifiable problem areas. With the aim of broadening the area of inquiry, the leading local publications have been reviewed. A study of the local media ${ }^{9}$ rhetoric was conducted with the goal of comparing the link to the heritage place by of the community of Pilies I village, of the town and the district of Jurbarkas. The outcomes of the inquiry and conclusions drawn from the surveys were weighted against some of the provisions in the Faro Convention, leading to the elaboration of some practical recommendations.

\subsection{The neighbouring community types of Panemunè Castle and their characteristics}

Heritage scholarship distinguishes between three major types of communities: rural territorial community, non-territorial rural community, and a complex contemporary community without leaving out its territorial -local aspect (Kuzmickaite [16]). The inquiry into the relationships between the local population and the employees of the castle has demonstrated that the community of the place indefinable as a heritage community is a complex contemporary community composed of the locals who currently work with VAA, the VAA 
staff commuting from other locations within the same district, and VAA staff commuting from Vilnius. These groups are connected by a common denominator - their expectations and activities are vested in the animation of Panemune. The population of Pilies I village, the actual site of the heritage complex, do not identify themselves as a castle community and do not function as a heritage community. The inquiry has laid bare the existing division between the local population and those individuals who are employed "by the castle" and on this basis are part of the heritage community. There have been several causes behind this division.

Panemunè Castle represents one of these cases in the Lithuanian heritage preservation when the safeguarding effort embraces material objects or items but no kinds of relations receive a timely attention. These are the relations between people and the heritage property, namely between the local population and the owner of the property, between the local population and the heritage authorities. Today Panemune Castle goes through the process of restoration conducted in stages (a part of the property has been restored, there is work being done on other parts, and there plans drawn for the remainder) and it is obvious that the property has no surrounding tradition. The people living next doors to the heritage resource have no connection to it. Lithuanian heritage researchers are unanimous on the point that in contemporary society, alongside with the classical ambition to preserve the items of heritage, we face an equally - if not more - important task of revealing the heritage to civil public (Markevičienè [17]). In order to avoid turning people into hostages of the heritage, to which they start feeling hostile (on the grounds of limitations and bans applied to the heritage properties), just educating on the heritage matters is not a sufficient measure. It is necessary to achieve that the public identifies itself with a particular piece of heritage a task that lies rather within a socio-cultural field then is a matter of the heritage preservation. The driving force in this process is tradition. "Over millennia societies evolved on the basis of the tradition - the most reliable means for the founding, fostering and maintaining group identity." (Markevičiene [17]). The history of Panemune Castle does not identify with the traditions of the local people. The case at hand lays bare a problem with the Lithuanian heritage preservation: major attention is dedicated to the safeguarding of the heritage properties and too small focus on the fostering of traditions, though a natural way to safeguard heritage. The results achieved with the heritage safeguarding measures are different from the effects gained through the fostering of tradition: "tradition nurtures, protects, upholds and communicates the knowledge and modes of operation, while the objective of the heritage preservation is to preserve the material relics of the past as a cultural resource with the aim of integrating them into the present cultures and handing down to generations to come." (Markevičienè [17]).

Panemune Castle seems to have a complicated fate: it changed hands numerous times over the history, and the owners, depending on their capabilities, were taking a better or worse care of it doing, repair and other work on the property. The inquiry into the role of the local people played over the course of the heritage identification/preservation process (especially prior to 1992 when the object was listed on the Cultural Heritage Register) has been done on the basis of a scholarly publication that covers the preservation process of Panemune Castle in the $20^{\text {th }}$ through the early $21^{\text {st }}$ centuries. Unfortunately, we can draw the conclusion that the activities prior to the listing as well as subsequently to it excluded the local population from the process. Sometimes even some essential information on the preservation works done on the buildings and their grounds failed to be provided.

Over the course of the study, various kinds of research in the field of community studies, among them, the results of the university studies, scholarly publications, and commissioned governmental investigations have been consulted, all with the goal of finding out 
about individual motivation to belong to a community. The main motifs that drive individuals to join a community are the willingness to make changes to social, cultural, economic and political processes that influence one's personal life and the desire to help solving of the existing problems (Matonyte [18]). The inquiry has found that most of the people of Pilies I village do not think of themselves as a "castle community" (though they see the value of the heritage property). It is possible to conclude, based on the words of respondents, that the artificially formed community (VAA staff, and the people from the village and Jurbarkas town employed at the castle) created a watershed between the local neighbourhood and the heritage. The exclusion of the villagers is further strengthened by their local expectations, which are in dissonance with a broader audience, which the owner and the heritage authorities envisage as interacting with the heritage. On the other hand, despite this exclusion, the impact of the current owners on the activities of the local population is immense (as obvious from the results of the inquiry). Therefore, the VAA-initiated activities should become a stronger presence in Pilies I village, some of them want to be tailored for the local neighbourhood. All the processes should to be managed in a responsible manner, because this will become part of the heritage in the future.

The study has identified a misconception of the heritage of the national significance: both the local population, and partially, the staff of the culture and tourism offices of Jurbarkas town tend to think that the heritage is there for tourists to enjoy. Surely, one can hardly find a contemporary heritage theory that does not encourage sharing, however, the awareness of and the identification with the heritage must come before. This misconception reveals one other aspect preventing local people from perceiving themselves as a heritage community. Panemune Castle is a heritage of the national level of significance, while its surrounding neighbourhood is a local community. The property is of significance not only locally, but also nationally. This leads to a contradictory stipulation that the local community, already burdened by its own problems, has to operate on a broader scene and get involved in the animation of the heritage with a vision of interests beyond their local scope.

\subsection{The heritage community within the Lithuanian heritage preserva- tion system}

Once we have identified the causes preventing the villagers of Pilies I from perceiving themselves as a heritage community, it is important to consider whether the state in general encourages the existence of such communities. The legal framework of the Lithuanian heritage preservation does not turn a blind ear on the smallest public organization a community - and its role in the process of heritage listing and animation. The theme of heritage and community is given attention in public discourse (e.g. the year 2016 was announced the Year of the Local Communities). However, the study has found that this approach is not actually applied in practice. Panemune Castle's case is typical for the Lithuanian heritage preservation: local communities are not being included into the process of identification and listing - thus afterwards they feel no need to actively contribute to the process of animation. This refers to a hole inside the procedure of heritization: when left aside, the community finds itself in disconnect with the property - therefore when the time comes to hand over the function of animation to the community, the authorities have to deal with their inactivity.

The discussion with the local population and the specialists from the cultural, heritage, tourism and education institutions operating in Jurbarkas town and around, have elaborated their concept of "Panemunè local community". In their minds it stretches beyond the village of Pilies I. Due to that, the study relied on another instrument for gaging the sense of the local community. We have reviewed the public discourse and rhetoric in 
relation with Panemune Castle with the goal of ascertaining the expanded concept of the local community. We have selected a leader weekly Mūsų laikas as a form of mass media for this purpose [19]. The restored wing of the heritage complex was opened in May 2013, therefore the newspaper issues from the beginning of the same year until February 1, 2016 were reviewed. The goal was to track a reflection in public rhetoric to the work of restoration and the opening celebrations. Of 156 issues reviewed, 24 carried articles, information briefs and announcements of upcoming events. The newspaper in general carries quite a few materials on the topic of heritage: they introduce the history of architecture, archaeology, artistic monuments, provide details on their condition, offer appraisal on events or other action in connection therewith. The number of materials connected to Panemune Castle (approximately eight in 52 yearly issues) is not small, given the fact that the newspaper covers all heritage properties located in the land of Jurbarkas which is exceptionally rich in heritage. Notably, all materials related to Panemune Castle (apart from announcements) never fail to note or stress that the owner of the property is VAA, not the municipality of Jurbarkas district. Thus, the mainstream rhetoric targeting the regional population shapes a general disposition towards the owner of the property as an outsider.

In summing up the study, it is important to bear in mind the limitations of the research. The discussion is focused exclusively on Panemune Castle, however, based on the assumption, that most of the national heritage properties located in the periphery find themselves in a similar situation, the recommendations are in no way tailored exclusively Panemunè.

\subsection{The activities and approaches by the local community in the light of the Faro Convention}

The population of Pilies I village, who provided their opinions, tend to view the works of the restoration and the animation activities in a positive rather than critical light, despite the emotional opposition between them and the castle employees. However, the neighbourhood is unanimous in giving the credit to VAA as the key actor in the current restoration and reanimation of the place. The Framework Convention on the Value of Cultural Heritage for Society defines cultural heritage as "a group of resources inherited from the past which people identify, independently of ownership, as a reflection and expression of their constantly evolving values, beliefs, knowledge and traditions. It includes all aspects of the environment resulting from the interaction between people and places through time." [1] In such cases of ownership as in Panemune Castle (when a property is owned not by the local community, nor by a local institution, nor privately), the main task is to preclude non-communication or conflict situations between the owner and the local population. The local people have to be invited and have all possibilities to freely participate in all events, actions and activities organized by the owner (this takes such measures as coordinating times of the events and ensuring free participation). Whether of national or local significance, the activities at the cultural heritage venue have to be primarily in favour of the local population.

The synergy of different communities has the potential of effecting the animation of a property on three levels: private, local and public. According to the Faro Convention: "The Parties to this Convention agree to: [...] take necessary steps to apply the provisions of this Convention concerning: [...] greater synergy of competencies among all the public, institutional and private actors concerned." [1] The heritage animation embracing the private, local and public levels opens up avenues for joint action at all stages of cultural property animation and inclusive of all people or institutions concerned with the heritage property. "In the management of the cultural heritage, the Parties undertake to: develop the legal, 
financial and professional frameworks which make possible joint action by public authorities, experts, owners, investors, businesses, non-governmental organisations and civil society." [1] The Department of Cultural Heritage should strengthen the activities focused on the private, local and public dimensions of heritage awareness, study, listing and animation. One of the methods of strengthening such efforts is the creation of regional expert groups who could interact with the local communities more closely and help the Lithuanian heritage system to open up and place civil society at its centre.

\section{The potential of cultural tourism}

The study of Panemunè Castle, the case of cultural heritage preservation of a property of high cultural value, has revealed ${ }^{10}$ that successful development of cultural tourism at Panemune lacks cooperation by its stakeholders, their deliberate strategies, an action plan and professionalism in the property management. There is no clear perception of the role of the heritage asset as an animator of the place. The opportunities to expand the range of services to tourists from resources available to the community are not explored to the full. The investigation into the field of cultural activities at Panemune has relied on the methods of analysis and synthesis and has been referenced by international literature. Semistructured in-depth interviewers have been conducted with the sampled groups: the administration of VAA, as the owner and manager of Panemune, with the representatives of the municipality of Jurbarkas with specialists of intangible heritage management. A SWOT analysis has been conducted. Analysed was statistical data on: tourist numbers, seasonal changes, grouping of tourists by visit purposes, duration of visits and the factors influencing their choices. Bearing in mind the divisions in the community of interested actors and their contradictory approaches, identified during the preliminary inquiry, the methods of interviewing and observation were of high value for the study. These interactions provided opportunities to gather, besides formal information, the messages carried by the behaviour of our respondents, by their body language, etc., and make forecasts of possible social processes, an impossible thing to do using other methods. The inquiry into social, cultural and artistic potential of Panemune Castle was conducted using the methods by Randal Mason of assessing the value of cultural heritage [20], inclusive of historical, cultur$\mathrm{al} /$ symbolic and social values.

The aim of the study conducted was a feasibility analysis of adapting of the heritage property towards cultural, social and economic needs of society and the local community. This objective is tuned with the Framework Convention on the Value of Cultural Heritage for Society which defines with transparency the most recent concept of the heritage and the criteria for contemporary heritage preservation strategies: trans-sector dialogue, social cohesion, professional development and economic potential [1]. Similar provisions emerge in the Programme for Cultural Properties' Actualization for 2014-2020 [21]. The programme perceives the actualization of the heritage as the adaptation of the property for "the cultural, social and (or) economic (strengthening the investment attractiveness of a territory or a region, creation of new jobs and an additional market, etc.) needs of the contemporary society and (or) the local community" [21].

\subsection{Overview of tourists visiting Panemunė Castle}

The complex of Panemune attracts both foreign and Lithuanian tourists. In 2015, it received 37,279 visitors ${ }^{11}$ (prior and during the restoration work, the data on the numbers of visitors was fragmented and imprecise). Most arrive using their own or individually arranged transportation - as this area does not have a properly developed transport infra- 
structure. The complex can be reached while driving along the old Klaipeda Road, yet neither the system of driveways leading to the castle, nor the railroad system are developed. Water transportation is not developed either, as the Nemunas River does not play any more significant role in the infrastructure of cultural tourism. The Nemunas waterway KlaipedaKaunas runs through Jurbarkas district: it is included into the network of the main inland waterways [7]. As noted in the publication, the EU funding was used to build docks for small boats on the Nemunas River: however, it is more a tourist attraction than a form communication between the castles on the river. The familiarization bicycle path follows a rather complicated route, yet even such as it is, it already increases accessibility of the castles for local and foreign tourists [7]. The problems of accessibility currently make the region of the lower reaches of the Nemunas River more attractive for local than incoming tourists. The opportunities to attract more visitors who are not motorized and come from more remote parts of Lithuanian are also limited.

Visits to Panemunè Castle feature in the routes of several Lithuanian travel agencies, but it is not regular. The administration of the castle has no agreements with the operators of cultural tourism. This region, however, has some of the best developed tourism routes and courses: the municipality of Jurbarkas offers nine main walks/routes: the Bicycle, Water, Nature's, Crafts', Crusades', Culinary Heritage, Museums, Castles and Manor Houses, and the Rulers' Roads ${ }^{12}$. Panemune Castle is but one stop integrated into them and is visited alongside with other cultural objects; there are no tourist routes developed separately for Panemune Castle, as a cultural heritage property and cultural tourism attraction. These circumstances have a strong impact on the duration of visits at Panemune Castle, which is, on average, two hours. The intensity of visits to the castle fluctuates with seasons, as it depends on seasonal work of the cultural tourism operators, and on the fact that most of the visitors stop at Panemune en route to their other destinations [7].

Visitors, depending on their aims for visiting Panemune Castle are categorized into those who step inside to see the exhibits of the castle museum and others, who only drop in to see the courtyard ${ }^{13}$. This method of grouping tourists by the castle administration does not strike as accurate. Tourists' choice is impacted by activities going on at the castle. When there is nothing going on, it makes no sense visiting the premises.

In summing up the information collected during the study, the main aims of visiting Panemune Castle are familiarization, recreation, education (the latter pursued mainly by local schools); despite of its huge potential, Panemune is not oriented towards attracting incoming tourists (from Lithuania and abroad).

\subsection{The motives behind visiting and failing to visit Panemunė Castle}

Short visiting times to Panemune Castle and not a very positive impression of the services prompted to review the archival event materials from 2015. Nine temporary projects were realized during this period (six exhibitions, a fair, a concert and a drama performance) and two continuous projects - the educational programme for children and weekend fairs held during summer time. It is obvious that such irregular and seasonal character of events does not promote tourism, and there is no tradition established as of yet for social, cultural and artistic activities [22].

The inquiry into the activities taking place at the castle reveals a resilient vision of "safeguarding" of the tangible cultural property, which is distant from the contemporary trends of cultural tourism wherein the intangible heritage is perceived as key element of the cultural heritage. This way Panemune finds itself in a situation where no new ideas are born in hope of creating the spirit of place needed to bring together the castle community and, finally, boost cultural tourism. The data yielded by the preliminary examination led to 
conclude that the formation of a local and international cultural tourism attraction centre at Panemune largely depends on the cohesion of all resources and cooperation of all interested actors. The existing resources (the castle complex, the community, VAA, Jurbarkas municipality) are capable of creating prerequisites for the improvement of tourism infrastructure and for the development of entertainment, educational and recreational programme. Therefore, during our second stage of inquiry we have dedicated a special attention to different interest groups and the future vision.

The local community has been found to be distanced from the community employed with the castle. The population of Pilies I who still recall the place as a former refugee home, later on, as a job opportunity, perceive the present day castle as the place where they are not needed, because they are unwelcome and cannot be useful to it in any way. On the other hand, the community takes pride in having the exhibitions of contemporary art as it sets their place apart among other neighbouring towns and villages. They are disposed to seek a mutually beneficial cooperation and propose more services and products reflecting the local context.

The creation of a strategy for the castle as a centre of unity for the local community and attraction to cultural tourists is above all compromised by differing approaches to the function of the castle and its future vision among the staff of the castle. All of respondents agreed with the need of having a professional manager for the place. The authors of study, taking regard of the nature of problems identified, are of the opinion that the place needs a cultural animator. Cultural animator is associated with the stimulation of the spiritual, physical and emotional life of people residing in a certain area, with due regard of their concrete socio-cultural circumstances, of problems and needs of contemporary society in general. For practical purposes, the animator provides support in solving all kinds of community troubles by consolidating their internal resources and by opening up the potential for creativity, and by initiating, organizing, supporting and coordinating public action.

Such a recommendation found support at the meeting of the representatives of the municipality of Jurbarkas and the community of Pilies I village where the ambition to revive the cultural life of the village was articulated. This could be achieved, they argued, by introducing a position in the community with the mission different from just creating more cultural events, but building of an active link with Panemune Castle, entering into a dialogue with the municipality and other interested actors in order to undertake a revival of the dwindling tangible cultural heritage.

The study has demonstrated that a sustainable development of cultural tourism at Panemune lacks a strategy of planning socio-cultural and artistic activities and an opportunity for trans-network co-operation. The current fragmentation of activities goes hand in hand with the absence of volunteerism spirit. The potential of intangible heritage is ignored, as there is no response to the changing concept of the heritage. The new approach places the relationship with the heritage asset, and the ability to recreate it and leave as inheritance at the heart of the effort. The visitors to Panemune Castle, both local and incoming, arrive led by aesthetic and sensory experiences, they create for themselves an image of the place based on their interpretation which is withdrawn from its real picture. However, the need to see things is felt ever more urgently. That is why the current function - only of letting the visitors to see the building from inside - is not sufficient. It is becoming increasing important to show, to communicate things. Panemunè lacks a more complex cultural package capable of recreating (creating) the spirit of place, by employing the synergy of intangible and tangible resources of the cultural heritage. 


\subsection{Practical recommendations to the stakeholders pursuing the effect of enhanced cultural tourism}

\subsubsection{The recommendations to the administration of Panemune Castle}

With the goal of invigorating the role of Panemune Castle as a destination of cultural tourism, we propose to refine the strategy of services provided to tourists, also, to initiate several yearly events possibly connected with the manor culture. In order to combat seasonal effect, it is better to have them during different seasons. It is advisable not to seek to emulate other practices but to bring into relief the inherent character of the region and the place with the help of culinary heritage, crafts and other communal and regional resources. In the development of a tourism services and entertainment package, an active cooperation with the hotel and the restaurant that operate in the castle mansion and other neighbouring providers of hospitality services would be a plus. It is necessary to build purposeful relations with travel operators and to provide them with a yearly plan of the events and services available at Panemune Castle. It is necessary, jointly with the municipality of Jurbarkas, with VAA, with other social and business stakeholders to promote the location on the mass media and social networks. It is essential to include the resources of the local community in the creation of the package of services and cultural products.

\subsubsection{The recommendations to Vilnius Academy of Arts}

In order to ensure a higher quality of operations of the castle administration, the Academy wants to take a more active part in the process of strategic planning of activities and to ensure monitoring of their implementation and quality. The role of VAA should be more prominent in the creation of artistic and educational programmes, the content of which is expected to reflect the character of the place, the needs of cultural tourism and the local community. It is a good idea to schedule cultural events for at least one year in advance, and the content of these events, their aims, character and participation opportunities have to be well known (and clear) to the management of the castle in order to insure a timely dissemination of information to different groups. The partnership with the hotel and the restaurant operating at Panemune, with the local community and the municipality of Jurbarkas needs to be developed with the goal of ensuring conditions for safe cultural tourism to Panemune Castle and its environs. VAA should act as a mediator between the administration of the castle and the local community promoting their partnership. VAA should explore its own resources in promoting Panemunè complex (by creating advertising functions, souvenirs and information for social media).

\subsubsection{The recommendations to the local community}

Carry on the negotiations with the administration of Jurbarkas district regarding the position of a manager/animator; organize an initiative group with the aim of exploring the needs of the community and their potential to promote cultural tourism in the village. Given the current conflict/passive relationship with the administration of the castle, use VAA as a mediator when considering the development of tourism services and products. Seek direct communication with the administration of VAA in the articulation of the expectations and problems within the community.

\subsubsection{The recommendations to the municipality of Jurbarkas}

The municipality should add extra effort to employ the resources of Panemune Castle and the neighbouring village of Pilies I as a potential for cultural tourism, including the 
promotion of cooperation between different institutions (initiatives) and the dissemination of information. Ways need to found to cohere the community of Pilies I village and to create for them a position of a manager/animator with the goal of exploring the initiatives within the community, and the current or potential resources for cultural tourism. It is also necessary to enhance (or create the conditions for improvement) the development of transportation, boarding and catering services. A consistent and regular communication with VAA on the cultural needs of the region, as well as intensified cooperation with the administration of the castle, VAA and the community of Pilies I village should create and ensure conditions for safe and vigorous cultural tourism

\section{The image as a resource}

According to Dawling Grahame, the image is an agglomeration of meanings through which people recognize and characterize an object, remember and connect to it (Dawling [23]). In the context of the contemporary marketing, the image of an organization is an entirety of ideas, feelings, perceptions and conceptions, entertained by an individual or a group towards an organization, which is influenced by material and non-material elements in the operation of the organization, by communication of individual as well as civic values (Drūteikienè [24]).

The analysis of the image of Panemune Castle as a resource of the heritage property embraced the following: theoretical background of the image of Panemune as a cultural heritage property, the range of problems connected to branding and ways to solve them. The study sought to identify the essential formative elements within the image and the results of their manifestation - all considered in the light of theoretical assumptions. The inquiry into the image as a resource of Panemune as a cultural heritage property pursued the following aims:

1. Description of the expressive quality of the image forming elements;

2. Discussion of a theoretical framework of the image of a cultural heritage property;

3. General recommendations on the meaningful development of the image of Panemune Castle using the contemporary instruments for cultural heritage branding.

In reference to the cited definitions of the image and its formative elements together with the perception of Panemune Castle and its environment as an integral "organization", we can assume that its tangible and intangible assets and the quality of their mutual connectivity determine the image of the castle. In December 2015, the researchers conducted a pilot and an in-depth study of the following: the Internet page at www.panemunespilis.lt; its Facebook account; the general context of tourism and educational programmes, information appearing on mass media and project activity. The semi-structured interviews were conducted with: the staff of the castle, the representatives of the local community, the representatives with the external institutions of the muncipality of Jurbarkas, the employees of the tourism centre of Jurbarkas, the staff of VAA - the creators of the web page of Panemune, and the students of VAA, who created the souvenirs. The work was done with goal of identifying the quality of Panemune functioning in different terms, including its image.

\subsection{Key paradigms in the making of the image of Panemunè Castle}

The study has revealed the following essential paradigms in the making of the current image of Panemune Castle:

1. Panemune image is dominated by the traditional elements of image shaping, put together in a haphazard manner: besides the information on the history of 
Panemune Castle and the architectural profile of the building, no strategic information is visible. The dissemination of the data on Panemune Castle is concentrated on niche matters, while an overall strategic image of the place is not existing or so indistinct that untraceable with scholarly instruments. The use of the traditional image shaping tools in the environment of contemporary communication limits the interpretation opportunities.

2. The existence of Panemune Castle is plagued by the conception of it as a constant entity and by a resilient vision of "safeguarding". This determines a long-running conflict between the "classical" and the contemporary approach to the valorisation of the cultural heritage. The local community tends to be in support of the classical path, while the community of VAA and the castle administration, as their representatives (also the hotel Best Baltic Panemunès Pilis, in part) pursue the contemporary vision for heritage. On the other hand, though, the Academy, by concentrating its efforts and the funding into the projects of restoration, also acts along traditional lines. Indeed, we here face a double problem. Not only does it suffer from a divided approach to the heritage between the proponents of the traditional and the contemporary philosophy. In fact, both sides, as we can sense from their rather fragmentary operations in connection to the place, do not rely on the foundational premise in the field of heritage. The material presence of intangible heritage creates a field of intangible values, if neglected, however, and not used for the holistic fostering of the place, they are likely to decay even faster than brick walls.

3. The image of Panemune Castle can be compared to a portrait of a fragmentary organism, painted simultaneously by several artists in different colours and a different manner. The faulty fragmentation is felt in the current functioning of the place, in the relationships of the staff, and the (un)interaction of the institution with the population living next doors. This fragmentary organism is at odds with a quality existence of the place, and makes impossible the creation of an image with the use of the contemporary strategies in the utilisation of the cultural heritage. As the current owner of the place, VAA should assume the responsibility for a narrowsighted operation of the cultural heritage property and take concrete steps leading to the creation of positive relations in the castle and around it, thus laying a firm foundation where the efforts of image building could start take root.

In a quick summing up, the expressive quality of the image-shaping elements of the place is insufficient, they appear behind the contemporary frameworks for cultural heritage. This raises theoretical questions as to what image shaping instruments should be employed in order to enhance the identity of the place and the image, and how they could connect to non-market values. According to researcher Jūrate Markevičiene [17], if a cultural heritage property remains unchanged, the picture of it does not change much either. However, with the changing images, people look at the heritage not at as something existing, but as something desirable, in other words, they modify the image - or, in the sphere of heritage, such images are linked to the imaginary past "golden age". We have already noted that the vision of "preservation" is especially resilient at Panemunè. The interviews with the individuals, who had a long history of connection to the castle, show that the intention is to preserve not only the structure and its architectural values, but also the experience and the models of utilising it as part of the tradition and habit. It is the attitude that by itself should not attract criticism, as the cultural heritage belongs to each of the country's citizens, but it determines a faulty attempt to project the imaginary "golden age" onto the present day.

In considering the meanings and symbols posited by images, the concept of the sense of identity or character, defined by Christian Norberg-Schulz as genius loci is greatly 
enlightening. In talking of towns, Vytautas Petrušonis also notes that each has a unique image (combined from a visual picture and a mental image - the genius loci) which is indivisible, but the essence of the place cannot be grasped if they are divided (Petrušonis [25]). The unique identity of a place and its purposeful employment subsumes also these essential for this study social agents as habits, traditions and myths, which may have a role in cultural tourism, in leisure and entertainment, and therefore are important in the chain of image building. The creators, observers and "experiencers" of Panemune image are the population, visitors, staff, remote virtual visitors (on TV, press, the Internet), the perception of whose place-generated messages is very important in the process of communication.

The theorist of architecture Indre Gražulevičiūtė-Vileniškè presents a structure of non-market assessment of immovable cultural heritage, providing also a detailed context. The author highlights the socio-economic aspects, as the role of heritage as a social and economic asset continues to be underrated, and the preservation of heritage properties is perceived as a burden on economic development (Gražulevičiūtè-Vileniškė [26]). Presented is one of the directions in the analysis of the socio-economic dimension of the cultural heritage - the assessment done in non-market terms:

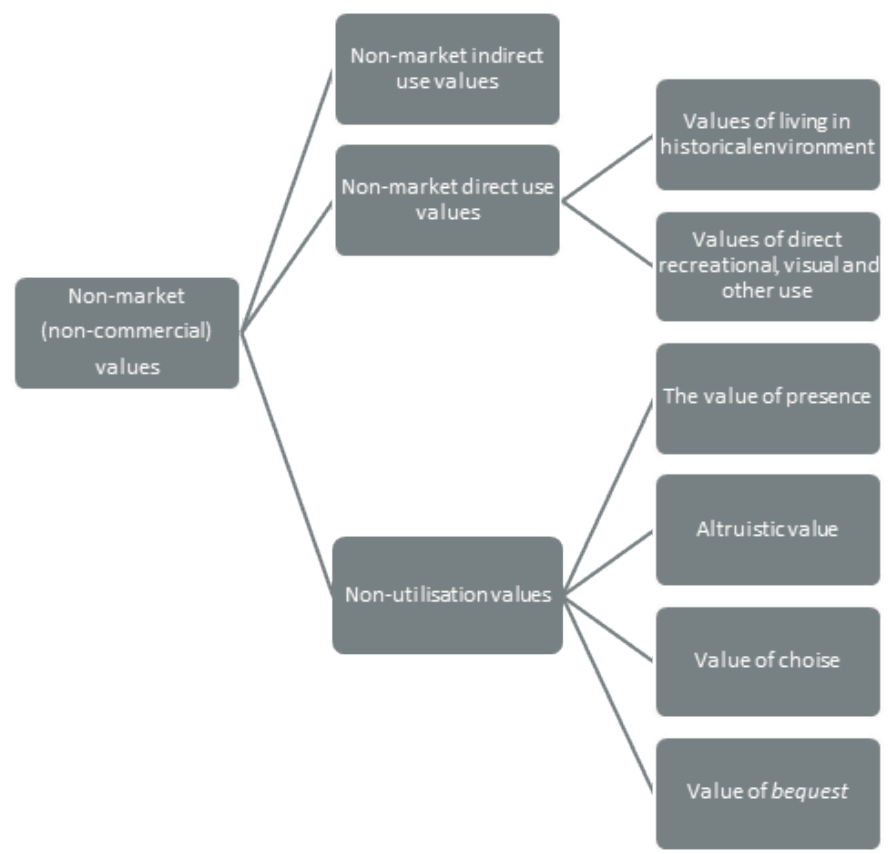

Ill. 3. Classification of non-market values of the immovable cultural heritage according to Indre Gražulevičiūtè-Vileniškè [26]

The non-market direct use is perceived as living in a historical setting without direct recreational, visual non-commercial utilisation of the heritage properties. The non-market indirect values are conceived as non-commercial indirect use experienced via books, other publications, TV or film. The value of presence (of the property) emerges in situations of individual satisfaction with the very fact of existence of the heritage property even without intent to visit it. The altruistic value is connected with the individual's wish to provide members of her/is generation (though not directly related individuals) with an opportunity of visiting the property The value of choice is connected with the individual's wish to keep 
the opportunity to visit the property in the future. The value of bequest connects to the individual's wish and intent to hand down the cultural heritage to generations to come.

As Gražulevičiūtè-Vileniškè plausibly argues, these non-market values may comprise the biggest part among the values of the property. The conception of non-market values underpins the case for the inclusion of society into the processes of heritage preservation and the assessments by the public have to feed into the overall process of assigning value. "This creates opportunities to establish the decrease in non-market utilisation and nonutilisation values of the heritage property as experienced by society in cases when the property is damaged or destructed, and an increase in value after the restoration of the property “ (Gražulevičiūtè-Vileniškè [27]). Society thus becomes an actively engaged actor, who, depending on communication strategies, also contributes to the creation of a new image, a new face or identity. It is unfortunate that in reality civic society is not included into assessment or the listing and animation processes of the heritage. The only exceptions are cases when the activist part of society, usually with political slogans, counters the acts of destruction of the heritage properties. All the above said holds true in the case of Panemune Castle. The interviews with the castle neighbourhood population and with the authorities of Jurbarkas show that the absence of a real discourse is not contributing to the value of the heritage.

Society thus becomes an actively engaged actor, who, depending on communication strategies, also contributes to the creation of a new image, a new face or identity. It is unfortunate that in reality civic society is not included either into assessment or the listing or animation process of the heritage. The only exceptions are cases when the activist part of society, usually with political slogans, counters the acts of destruct of the heritage properties. All the said holds true in the case of Panemune Castle. The interviews with the castle neighbourhood, and individuals representing the authorities of Jurbarkas show that absence of a real discourse generating some added value to the heritage.

It is obvious that the development of a local or international image takes a solid semantic foundation, and one of the ways to discover it is outreach to society. The idea of a museum "safekeeping" its exhibits has to be given up, and the properties under protection have to be used as "semantic and semiotic depository of the world culture" (Rudokas [28]). The architecture theorist Kąstytis Rudokas, when discussing important methods of enriching the identity of cultural properties, points to public creativity. "It creates new meanings and new narratives in a place of a strong identity or cultural emptiness, thus expanding the sense of a material and static object" (Rudokas [28]). The arguments by the cited researchers lead to believe that image shaping does correlate with non-market values, especially with the values of non-market direct and indirect utilisation.

We have already used the analogy of a fragmented organism when discussing the image of Panemune, wherein each segment, by its presence and through its operation, aspires for positive results, and even has an intuition of the non-market values of the castle. None of them is harming the existence of the castle as a cultural heritage property. However, the inability of mutual communication and the absence of a coherent strategy, the lack of a common sense-giving ground, not only deter the process of the contemporary heritization and animation, but interfere with the shaping of such an elementary characteristics as the image of place. Before the contemporary strategies of cultural heritage property utilisation are put into action, they need to be preceded by the monitoring, strategic planning and maintenance programmes. In other words, the image of Panemune Castle should be perceived as a value-adding resource, shaped in an integrated manner, by including all the interested public groups; the quality of its expression should be monitored on a constant basis. 


\subsection{Proposal for a castle myth and a semantic ground for the image}

The history of the castle and the values of the landscape, as well as the life style of the castle dwellers could be a reference point for building a unified semantic foundation for Panemune. Such conclusions and proposal are generated using the pilot research conducted in December 2015. The Panemune myth inevitably connects to the residential character of the architecture. The castle was founded not entirely as a defence structure in the narrow sense, but was also a residence of Janusz Eperjesh family. When owned by the Gelgaudas family, Panemune retained its residential character, even when Stanislovas Puslovskis converted its west wing into a granary, the south wing kept its residential function [29]. During the First World War, Panemune was put to a different from its original purpose use; while during Soviet times, it regained its residential function. Currently the operator of the Best Baltic Panemune Pilis also offers accommodation services. The thread of actual living in the place has not been interrupted. Based on the interviews with the individuals who used to live in the castle, they still feel nostalgic for the golden age, e.g., tell stories of having lived in the castle. Even though we have offered criticism regarding the modern day projections of the golden age, it is possible to use it with creative transformations for the making and enforcing a myth about its residential purpose. This example is used to illustrate how the image of Panemunè can be created in the context of non-market values, and how it can be used as a full-fledged asset.

\section{The economic value: current and emerging}

As the $1970-1980$ s saw the economic value of cultural heritage grow in significance, as noted by Agnè Vaitkuvienè [30], the concept of heritage preservation shifted from the passive conservative paradigm to the active management of resources, prompting also the emergence of the heritage industry. The museums of the $19^{\text {th }} \mathrm{C}$. used to be education and culture institutions, these days they become financial institutions, heritage centres, while the museums are transformed from the depositories of antiquities into modern culture objects. In Lithuania, the rise of the heritage industry should be linked to the growing economy of the 1990s and the increasing purchasing power (Vaitkuviene [30]). On the other hand, the emerging economic values leave open doors for risks such as pursuit of material profits, which means commodification of the heritage and placing at stake (by default or by intent) the criteria and/or values of authenticity.

Lithuania is part of the global constantly changing world, thus the national heritage preservation policy should also be tuned to the world trends in safeguarding the heritage. It is wise to make use of the strategic management instruments and be guided by the international legal documents ratified in the country. The investment into revival and fostering of the cultural heritage and expansion of this field contributes to the employment opportunities and the growth of welfare. The development of the cultural heritage as an independent field influences numerous other fields of human activity. It always helps to strengthen the region wherein the heritage property or properties belong.

The district of Jurbarkas is exceptional in Lithuania due to its rich cultural heritage and its solid potential that can be utilized in boosting regional and national economy. Panemune Castle does not dominate the heritage scene of the district, but is part of it. In 2013, Panemune was adapted for tourism needs. In our analysis of the entirety of its values, therefore, the economic value plays a role of importance. The aim of this part of the study is to demonstrate the impact of the cultural heritage property's economic value on the development of the area. Pursued are answers to the questions as how the partial adaptation of the residential castle for 
tourism needs reflects on the region's economic situation? What were the obstacles preventing more prominent manifestations of the impact of its economic value?

\subsection{Defining the socio-economic situation of the district of Jurbarkas}

The economic and social indictors for the district of Jurbarkas depend on the general trends in the country and the characteristics of the district. Two towns, seven historical boroughs and 355 villages belong in the municipality of Jurbarkas. According to the data of the Lithuanian Statistics Department, on 1 May 2015, 30.4 thousand individuals declared their place of residence in the district of Jurbarkas, 11.33 thousand in the town of Jurbarkas. The district is highly homogeneous, as 98.7 per cent of the population are Lithuanians [12]. The study of social and economic aspects of the district has found that high rates of unemployment, population aging and migration bring it together with other problem areas of Lithuania. The probing of the investment climate of this culturally rich land shows that a considerable financial support has been offered to the agricultural activities linked to production and realization. Small-scale start-ups and developing business have also received support. Some measures have been implemented with the aim of increasing the economic value of the cultural heritage properties. Considering the measures aimed at the bettering of investment climate in the district, quite a few of them have been found in direct connection with the boosting of cultural tourism. The town board of Jurbarkas, in shaping a long-term strategy for the district, took into account its rich cultural environment, an additional internal resource for the development of the district. Jurbarkas is interested in investment needed as help for putting the present potential into use, but the coming of investors is deterred by the shortage of information on starting and developing a business. In order to remove this stumbling block, the municipality committed itself to [31] regular collection, systematization and dissemination of information on the district's real property market, its natural resources, services, communication network, land and forest resources, the legal basis, as well as ways and conditions for investment.

Cultural tourism nowadays attracts visitors by offering an experience of place identity, e.g., local traditions connected to the place, culinary heritage, stories and narratives. The opportunity to offer more and richer services has not yet been explored at Panemune, something desirable by the local community. The local population are not able to start business for the niche of cultural tourism on their own. They need to be given the knowhow "injections" and good practice models to follow. Such guidance and assistance should be provided in a manner accessible and comprehensible to the local people. Another unexplored avenue is to increase the exposure of Panemune logo: the brand logo needs to become a better visible fixture of the district of Jurbarkas, a familiar sign sending a message of attractive cultural tourism service. A strong image in its own turn would provide a shot in the arm for the emerging services and products.

\subsubsection{The regional investment climate of Jurbarkas}

According to Rūta Garalienè and Giedrè Belazarienè, "social and economic growth is possible only with the growth of investments (including foreign investments). The state is incapable of allocating funds for investments required for the achievement of an economic effect. This problem can only be solved by creating a climate of investment attractive for both foreign and local investors" (Garalienè, Belazarienè [32]). The authors argue that even ineffective investments contribute to the improvement of the climate by creating an infrastructure and by paving the way for the effective ones. A distinctive regional character and the objects/places of attraction are among the most important factors contributing to a climate potentially attractive for investment. The district of Jurbarkas in these terms is an ideal area. 
The Lithuanian Government resolution On the approval of the development programmes of the problem territories ${ }^{14}$, noted that investment in tangible fixed assets per capita in the district is 3.3 times less than the national average. The municipality of Jurbarkas district has 3.3 times less of foreign direct investments than its county centre, the municipality of Taurage district. In order to cope with this backwardness, the municipality of Jurbarkas district promoted the start and development of small-size business, providing support from the municipal small-size business support fund. The municipality stands out in terms of foreign investments which exceeded by over 13 times the municipalities of Pagegiai and Šilale, similar to Jurbarkas in their size and character.

In 2008, there were 22 local rural communities, 28 of them in 2010 . They were united into a local municipality's action group Nemunas. They relied on the EU support to develop and start implementing a strategy for 2009 - 2015 aimed at the expansion of the group's activity and encouraging the local people in the problem area engage more in communal activity by using the EU support.

With the goal of attracting investments into the district, on 26 July 2012 the Council of Municipality approved The 2012-2020 plan on measures for attracting investment by resolution (No. T2-208) On the approval of a 2012-2020 plan on measures for attracting investment into the municipality of Jurbarkas district. [33] Measure 1 of this plan prioritizes jobscreating-projects within the general scheme of municipal budgeting of investments and in cases of municipal partnership in projects. In 2011 - 2012 the municipality completed a project financed from the EU structural funds Adaptation of the Imsre River banks for public infrastructure. ${ }^{15}$ The banks of the river were adjusted for an active, healthy life style. Along the river, bicycle and pedestrian paths, children's playing grounds and sports grounds were built. Tourist information stands were installed by the river. This created one new job place. The projects Modernization of Pilies I village water treatment system ${ }^{16}$ and Adaptation of Seredžius for public tourism infrastructure have each created one new job place.

\subsection{The implementation of enhancement measures for the investment environment}

The municipality of Jurbarkas district seems to dedicate substantial attention to the task of attracting investment. Some of the measures under the 2012-2020 plan on measures for attracting investment are directly connected to the development of cultural tourism. The long-term strategic development plan approved by the municipality of Jurbarkas district in 2014 defines a vision anchored to the cultural and natural uniqueness of the district. In shaping a long-term regional perspective, the Town Board went to the local cultural-natural resources as an internal development asset. In 2015, a Programme for the promotion of small and medium-size business and tourism was approved by the municipality with the goal of boosting the populations' entrepreneurship skills and attracting investments by the local and foreign companies into the area of scenic nature (an ideal setting for recreational visits), rich in the cultural heritage of the international and national significance.

A range of cultural events aligned with the expectations of the local population and the national cultural agenda contributed significantly to the shaping or the image of the region. Noteworthy are the following events: small ship festival Jurbarkas on the Nemunas River dedicated to the promotion and development of shipping; biennial international folk festival On Water held in Jurbarkas town and Panemunè Castle; a long-running professional and amateur art festival Blossoms of the Riverside, held at Raudone Castle, and the national art festival The Echoes of the Castle held at Panemune. In 2015, weekend craft workshops were organized on regular basis. Community members were provided with the opportunity to introduce the land of Jurbarkas to incoming tourists. Though some of the 
projects helped to adapt the objects of cultural tourism for visiting, the 2016 - 2026 strategic development plan notes ${ }^{17}$ that the flow of tourists lacks intensity and identifies shortfalls in the infrastructure. The document also states that it is necessary to look for new ways to spread the message about the area [31].

The steps taken by the municipality have been effective and the work directed at the strengthening of the attraction of the cultural heritage in the region contributed to the bettering of investment climate. However, the effort was partially compromised by fragmentation of activities and was not fully subsumed by the strategic goal for the cultural heritage as part of the broader regional development process. The resources, institutions and individuals need better orchestration in order to achieve greater efficiency in the management of regional economy. Cohesive management is achievable through a systemic strategic planning and search for alternative forms of development and monitoring.

\subsection{The current and potential impact of the revival of Panemunè Castle on the development of the district of Jurbarkas}

The opening of Panemune Castle for tourists brought about the need to manage tourist flow. This issue was addressed by the administration of VAA, the staff of the castle, and the tourism and business information centre of the municipality. The educational and museum functions in the castle are complemented with the accommodation and catering services provided by a 4-star hotel operating in the castle. These new accommodation and catering services in the castle contribute to the process of coherent regional development of tourism. The investments used for the reconstruction and adaptation of the castle helped to create eight new job places connected with the preservation and conservation of the cultural heritage.

The impact of the revival of Panemune Castle as a heritage property on other fields can be best measured by the emergence and development of specific activities. The surveys conducted over the course of the study facilitated in making a realistic SWOT analysis of the present and created economic value of Panemune Castle.

\subsubsection{Strengths}

The strengths of Panemunè as an economic value generating property are connected primarily with its features as a cultural heritage. It is the best preserved of the extant $17^{\text {th }} \mathrm{C}$. residential castles in Lithuania. Considerable work has been done in developing the infrastructure for tourism which now contributes to the development of cultural tourism. Panemune Castle, as part of the Panemuniai Regional Park, can strengthen its appeal as a cultural tourism destination through cooperation with the regional park. Its scenic natural setting and the picturesque complex of the residential castle is a perfect location to organize community functions and holidays. The castle is equipped with a conference centre that serves communal needs for conferences and meetings. It is a venue of different events, including educational workshops for children and young adults, exhibitions and other occasions, always supported, within their means, by the local entrepreneurs, even though the district cannot boast of many well-developed businesses. In the summer, visitors to Panemune are invited into weekly fairs with sporadic participation of the local community who sell their produce.

\subsubsection{Weaknesses}

Though the revived castle is attractive as a cultural heritage property, without a longterm strategic plan for cultural tourism at Jurbarkas Municipality (it now happens through sporadic initiatives), its reopening has not become a significant incentive for the regional development. It has not been capable of attracting new investments into fields relevant to 
cultural heritage. The insufficiencies of the infrastructure remain a hindrance to the development of cultural tourism. The infrastructure needs enhancement in order to ensure a more vigorous inclusion of the neighbouring communities into the process of promoting cultural tourism to Panemunè Castle.

When interviewed, community members noted that they do their best to take their guests or visiting family round the castle, yet it is not always possible due to private functions held at the castle by individuals or organizations. Seasonality also has an impact on cultural tourism: winters see the flow of incoming tourists drop, in the summer, their numbers increase and make it difficult to offer quality services to the arriving groups. Most of cultural heritage tourists visit Panemune en route, as the 4-star hotel's services are rather expensive.

The castle currently has a limited selection of souvenirs for different groups of visitors.

The project to build a cable car crossing over the Nemunas River in the district of Šakiai is put on hold. The crossing would intensify regional cultural tourism and ease the access for the cyclists from the cycling route along the river to the sights on both of the banks. However, the issues connected with the building and maintenance of this tourist object are quite complex.

\subsubsection{Opportunities}

The development of the infrastructure of public communication, better information on public transportation to the castle, a section of information for disabled people - these measures would encourage different groups of visitors to travel to Panemune Castle more often.

The local community has wished to enrich the package of services on offer and to embrace the cultural identity of the place more fully, with its traditions and culinary heritage, etc. This connects to the inclusion of local business into the castle activities and with the development of volunteerism in the field of cultural heritage. The castle staff can contribute to the fostering of volunteer skills by training the young guides and volunteer helpers of other age groups. The content of the services can be greatly enriched by making use of the human resources, e.g., contributions by teachers, librarians and other individuals.

\subsubsection{Threats}

The shrinking financial resources would be a real threat to the owner of the castle for the development of cultural tourism in the area. Such threats may be counteracted by the cooperation with potential stakeholders, by offering more services of adequate quality. New services can increase the attraction of the location and increase numbers of cultural tourism, contribute to the growth of welfare of the population of the area.

\subsection{Practical recommendations: towards enlarging the economic value of Panemunè Castle}

Vilnius Academy of Arts, the owner of Panemune Castle, in cooperation with the stakeholders, the local communities, the cultural and education institutions, wants to develop a strategic action plan for the castle, highlighting the following strategic directions: quality of presentation of the buildings and the natural heritage to the public; community inclusion; regional cultural tourism development in the long-term and coordination of it; model for castle management and other questions connected with the sustainable development of the heritage property and the area. This plan is wanted in order to ensure the economic efficiency and profitability of the castle, as well as the inclusion of the regional community into the process of creation of communal welfare. Recommended is also 
a practice to develop and make public annual plans for events, streamlining such plans with the national cultural tourism framework and the needs of the regional communities.

With the help of the Academy staff involved in the management process of Panemune, a joint vision, mission and values for the place wants to be created and revisited yearly. The commitment to such a joint vision would give an additional stimulus to the potential collaborators to cooperate in the expansion of services connected to the castle.

VAA as the manager of the property would profit from a close cooperation with other residential castles of the $17^{\text {th }} \mathrm{C}$. in Europe, especially in the Nordic countries with plenty of good experience in the field of cultural tourism development and the impact on regional development. Such cooperation and instructional tours to the castles of Nordic and other European countries are likely to help to equalize cultural tourism standards regionally and to contribute to the improvement of cultural tourism services.

\section{Conclusions}

1. The contemporary system of the Lithuanian heritage preservation lacks equity in assigning attention to the different elements that contribute to the entirety of values in a cultural heritage property, inclusive of its social, cultural, artistic significance, impact on local communities and significance of cultural tourism, the role of cultural heritage brands and economic efficiency of the heritage. The study of different aspects of this entirety of values - of each separately and collectively - has brought to the conclusion that in the case under analysis the social, cultural, artistic and economic values have an impact on the environment, but do not become a powerful driving force of the contemporary cultural heritage preservation process. They are used and function in a fragmented, sporadic and undeveloped manner, failing to achieve a maximum synergy effect on the place.

2. The heritage community will operate successfully when the Academy community stops turning a blind eye on the local population (both, of Pilies I village, and the district of Jurbarkas). On the other hand, the local community needs to reinvent itself, to respond adequately to the emerging problems and, above, to give up attempts to halt the process of innovation. The fact of the existence of the castle community, the local village community, as well as the community of Jurbarkas land tending to identify themselves with Panemune Castle, can be used as a feature of a modern and contemporary environment for the heritage property to function in. It is paramount that these very distinct (yet closely connected) communities build mutual links and their activities do not antagonize the rest. If achieved, the synergy of these communities has the potential of animating the heritage property on three levels: private (internal motivation), local (by joining together local population, not necessarily people who know each other, by inclusion of the local institutions, organizations), and public (outreach acts, communication of communal interests on the broader scale, inclusion of public institutions, e.g., governmental agencies). The animation of the heritage on these three levels opens opportunities to take joint action during different stages in the life of the heritage property (like listing or animation) and in agreement with all individuals or institutions connected with the heritage object.

3. The animation of the heritage property of national significance cannot be trusted into the care solely of the local community on grounds of its significance and the scale of responsibility, therefore a thoroughly planned and consistent support to the local communities needs to be given in a variety of forms and means. One of the best ways the State may opt for in providing clarity and support to the local communities similar to the one living in the neighbourhood of Panemune Castle, is to ratify the Framework Convention on the Value of Cultural Heritage for Society, or the Faro Convention. The coming into force of 
the Convention, not necessarily nationally, but mainly in the regions, would result in possible and proactive changes in the heritage field of Lithuania.

4. In cooperation with the regional business, cultural and educational institutions, VAA, as the owner of Panemune Castle (VAA), should develop a strategic action plan for the castle, highlighting the following strategic directions: quality presentation of the buildings and the natural heritage to the public; community inclusion; the long-term regional cultural tourism development and coordination; model for castle management and other questions connected to the sustainable development of the heritage property and the area. This plan is needed in order to ensure the economic efficiency and profitability of the castle, as well as the inclusion of the regional community into the process of creation of communal welfare. Recommended is also a practice to develop and make public annual plans for events, streamlining such plans with the national cultural tourism framework and the needs of the regional communities. With the help of the Academy staff involved in the management process of Panemune, a collective vision, mission and values for the place wants to be created and revisited yearly. The commitment to such a joint vision would give an additional stimulus for cooperation.

5. The image of Panemunè Castle can be described as a fragmented organism wherein each segment, by its presence and through its operation aspires for positive results, and even has an intuition on the non-market values of the castle, and none is harming the existence of the castle as a cultural heritage property. However, the inability of mutual communication and the absence of a unified strategy, the lack of a common sense-giving ground, not only deter the process of the contemporary heritization and animation, but interfere with the shaping of such an elementary characteristics as the image of the place. Before the contemporary strategies of cultural heritage property utilisation are put into action, they need to be preceded by monitoring, strategic planning and maintenance programmes. In other words, the image of Panemune Castle should be perceived as a valueadding resource, shaped in an integrated manner, by including all the interested public groups; the quality of its expression should be monitored on a constant basis.

6 . The municipality of Jurbarkas district is becoming more convinced about the activity connected with the cultural heritage as a field of importance and the potential capable to improve the regional investment climate, and contribute to the growth of economy, regional and the national. As a result, action is taken to further enhance the environment features beneficial for the cultural heritage. The first stage of the work of adapting Panemune Castle for visitors gave a good start to energize the regional cultural tourism, to design and introduce high quality services in relation to it, to introduce considerable variety into the regional educational and cultural life. The SWOT analysis has identified both successful shifts and the hindrances the removal of which would help to improve the expression of the economic value of the castle and contribute to the regional investment climate.

\section{Notes and comments}

1. The researches by the scholars of Venice University J. van der Borg, P. Costa, G. Gotti conducted in the towns of cultural heritage, Aix-en-Provence, Amsterdam, Bruges, Florence, Oxford, Salzburg and Venice corroborate the thesis of beneficial cultural heritage impact on the development of the area [34]. Torunn Herje gave an example of a prominent cultural heritage impact on regional changes in Norway. T. Herje (Lehtimaki [35]). A positive impact of the cultural heritage on regional growth has been presented in the studies of the Irish heritage [36] as well as in the research by Z. Kobylinksi [37]. 
2. A visit to Panemune Castle and the town of Jurbarkas took place in December 2015, information was collected and systematized prior to the visit and after it.

3. Respondents: Project head of Panemune Castle, head of Panemunė Castle, custodian of the castle's permanent exhibitions, manager for tourism, tourism and business information centre of Jurbarkas, methodologist of centre for education in Jurbarkas, a senior specialist of culture subdivision of the municipality of Jurbarkas district, a specialist of ethnic culture subdivision, conservator of culture section of the municipality of Jurbarkas district, local countryside tourism operator, chairwoman of Pilis village community, villagers from Pilies I (4 individuals), elder of Skirsnemunè eldership. The names of respondents are known to the authors of the publication [38].

4. The Immovable Cultural Heritage Assessment Council of the Department of Cultural Heritage under the Ministry of Culture of Lithuania adheres to this type of analysis in assessing properties and preparing materials to the Register of Cultural Properties and uses this methodology system.

5. The original Eperjesh project was of the Renaissance style supposedly built to the design by the Dutch architect Petr Nonhart.

6. The webpage of Panemune Castle [22] presents detailed information: The aims of the project: the first stage of the reconstruction and adaptation work of the south wing. This part of the project defines its first stage. After completion of this stage of work, the south wing of the castle will be able to function as a minimal, but a fully-fledged, quality tourism infrastructure. The works under the project will keep the castle's authenticity, the complex will be ready to provide public services to tourists and to the local community, and will contribute to the coherent expansion of the route of castles along the River Nemunas. The project also includes adjustments required for disabled visitors. The implementation of the project embraces the following works: a) repair works of the structural components of the south wing (including work on the plinth, walls, installation of water draining system on the buildings; b) installation of a fire alarm system in the south wing; c) adjustment of the object for the needs of disabled visitors: installation, for that end, of a video camera in the tower of the castle, which feeds real time images of the surrounding environs to the monitor located at the tourism centre on the ground floor of the south wing; d) relocation of the tourism centre to the premises adapted for that purpose, purchasing of equipment and furniture; e) recreation of the former kitchen, originally situated on the ground floor, to be integrated into exhibition part be open for public.

7. The conversation took place in December of 2015.

8. V. Ščiglienè, Patrimonialization paradoxes in Lithuania and opportunities for good practise. In: How to asses built heritage? Assumptions, methodologies, examples of heritage assessment systems. Comp. Boguslaw Szmygin. Polski Komitet Narodowy ICOMOS; Romualdo Del Bianco Foundatione; Politechnika Lubelska 2015. ISBN: 978-83-940280-3-9. P. 219-240; V. Ščiglienè, Ipaveldinimo praktika Lietuvoje: ypatumai ir naujos galimybès. In: Kultūros paminklai. Nr. 20, 2016. p. 3-18.

9. The study into public rhetoric was conducted by K. Daubarytè.

10. The study uses research data presented in the MA theses by Kristina Palšyte [10] and Rimante Déringyte [9].

11. Data by Panemune Castle (visitor centre) staff.

12. According to the data by the tourism and business information centre of Jurbarkas.

13. Tourist numbers are recorded by the castle staff and may be imprecise; 
14. Government decree of the Republic of Lithuania „Dèl probleminių teritorijų plètros programu patvirtinimo" (On the approval of the development programmes of the problem territories, 18 May 2011 No. 588) (Žin., 2011, No. 64-3031).

15. VP3-1.3-ŪM-05-R measure The enhancement of regional public tourism infrastructure and services. Total project value 2,682,585,00 Lt, of these - 2,278,947,02 Lt (85 per cent) from the EU Structural Funds.

16. Measure Revival and development of the countryside.

17. 30 January 2014. No. T2-1.

\section{References}

1. Council of Europe Framework Convention on the Value of Cultural Heritage for Society, Portugal, Faro, 2005 [interactive] [accessed on 4 April 2015]. Available from:

$<$ http://conventions.coe.int/Treaty/EN/Treaties/Html/199.htm>.

2. Fairclough G., Dragićević-Šešić M., Rogač-Mijatović L., Auclair E., Soini K., The Faro Convention, a New Paradigm for Socially - and Culturally - Sustainable Heritage Action? Култура / Culture, 8 /2014 [interactive] [accessed on 17-06-2015] Available from: $<$ http://journals.cultcenter.net/index.php/culture/article/view/111>.

3. Smith L., Uses of Heritage, London and New York: Routledge, 2006.

4. Harvey C.D., Heritage pasts and heritage presents: Temporality, meaning and the scope of heritage studies. International Journal of Heritage Studies 7(4) (2001).

5. Panemunès pilis. Kultūros vertybių registras [interactive] [accessed on 1803 2016] Available from: $<$ http://kvr.kpd.lt/\#/static-heritage-search $>$.

6. Gudienė V., Panemunès pilis. Vilnius: VDA leidykla, 2005.

7. Jurevičienè J., Burinskienė M., Genytė I., Šiupšinskas G., Kalibatas D., Inovatyvūs regeneravimo metodai ir ju modeliavimas: Panemunès pilis. Monografija. Vilnius: VGTU leidykla Technika, 2014.

8. Butvilaite R., Panemunès pilies tvarkybos raida XX a. - XXI a. pradžioje. In: Acta Academia Artum Vilnensis. Vilniaus dailès akademijos leidykla, 2015, pp. 241-271.

9. Dèringytė R., Kultūros animatoriaus vaidmuo analizuojant kultūros paveldą. Panemunès pilies atvejis. Vilnius, VDA, 2016. Supervisor Assoc. Prof. Dr. V. Ščiglienė.

10. Palšytė K., Nematerialaus paveldo vadybos strategijos materialiuose kultūros paveldo objektuose: Panemunés pilies atvejis. Vilnius, VDA, 2016. Supervisor Assoc. Prof. Dr. V. Ščiglienė.

11. Lietuvos Respublikos Nekilnojamojo kultūros paveldo apsaugos istatymas (Law on Protection of the Immovable Cultural Heritage). 22 December 1994. No. I-733, Vilnius. Published in: Žin., 1995, No. 3-37. [interactive] [accessed on 04-12-2014].

Available from: $<$ http://www3.lrs.lt/pls/inter3/dokpaieska.showdoc_l?p_id=458428>.

12. [interactive] [accessed on 201602 15] Available from: $<$ https://osp.stat.gov.lt $>$.

13. Convention on the Protection and Promotion of the Diversity of Cultural Expressions. Paris, 20 October 2005 (came into force 18-03-2007). Ratified by the Republic of Lithuania 14 December 2006 Law No. X-983. Published by Valstybès žinios, 2007, No.1-4. [accessed on 18 March 2016]. Available from:

$<$ https://www.e-tar.lt/portal/legalAct.html?documentId=TAR.56852F0E1FD0>.

14. Convention for the Safeguarding of the Intangible Cultural Heritage. Paris, 2003 (Came into force 20.04.2006). Ratified by the Republic of Lithuania on 9 December 2004 by the Law No. X-37. [accessed on 17 March 2016]. Published by Valstybès žinios, 2004, No.188-7006. Revised translation in Valstybès žinios, 2013. No. 115-5734.

Available from: http://www3.lrs.lt/pls/inter3/dokpaieska.showdoc_1?p_id=248105\&p_tr2=2.

15. Québec declaration on the preservation of the spirit of place, Adopted at Québec, Canada, October 4th 2008. [interactive] [accessed on 1903 2016].

Available from: <http://whc.unesco.org/uploads/activities/documents/activity-646-2.pdf $>$.

16. Kuzmickaite K.D., Lietuvos bendruomeniu tipologija ir ypatumai. Socialinè ekonomika: vietos bendruomenès poreikiai ir galimybès. Socialinès ekonomikos institutas, 2004. 
17. Markevičienè J., Senamiesčio j̣vaizdžiai Vilniaus kultūros paveldo saugoje XX a.: nuo kraštovaizdžio iki praeities skeveldrų. Iš Kultūrologija 10: Kultūriniai tapatumai ir pokyčiai. Vilnius: KMI, 2003.

18. Matonytė I., Žmogaus socialinè raida ir pilietinè visuomene. Viešosios politikos studijos 1(2): 4-20, Viešosios politikos tyrimų centras, 2002.

19. Jurbarko miesto ir rajono laikraštis Mūsų laikas (Jurbarkas town and district paper Müsu laikas) [interactive] [accessed on 14022016 - 2203 2016]

Available from: $<$ http://www.mūsųlaikas.lt/el-laikrasciu-archyvas $>$.

20. Assessing the Values of Cultural Heritage. LA: The Getty Conservation Institute, 2002, p. 1112. [accessed on 2 April 2016]. Available from:

$<\mathrm{http} / /$ www.getty.edu/conservations/publications_resources/pdf_publications/pdf/assessing.pdf $>$.

21. Regarding the changes to the 2014-2020 programme approved by the Minister of Culture by decree No. Ivv-711 of 6 October 2014 „Dèl kultūros objektų aktualizavimo 2014-2020 metu programos patvirtinimo" (On the Approval of Cultural Objects Actualization Programme for 2014-2020) [interactive] [Accessed on 0203 2016] Available from: <https://www.etar.1t/portal/1t/legalAct/ea3227100f6f11e5920c94700bb1958e >.

22. Panemunés pilis (webpage). [interactive] [accessed on $21 \quad 03$ 2016] Available from: $<\mathrm{http}: / /$ www.Panemunèspilis.lt/?pg=121>.

23. Dawling G., Managing your corporate images. In: Market Manage 15 (2), 1986;

24. Drūteikienè G., Organizacijos ịvaizdžio kūrimo procesas ir jo vadyba. Daktaro disertacijos santrauka. Vilniaus universitetas, 2003.

25. Petrušonis V., Vietovès kultūrinio tapatumo subjektinis substratas. Urbanistika ir architektūra, t. XXVI, Nr. 1, Vilnius: Technika, 2002.

26. Gražulevičiūtè-Vileniškè I., Nekilnojamojo kultūros paveldo ne rinkos vertinimas: teorinis kontekstas ir galimybès. Daktaro disertacija. Kauno technologijos universitetas, 2009.

27. Gražulevičiūtè-Vileniškè I., Nekilnojamojo kultūros paveldo ne rinkos vertinimas: poreikis, galimybès, reikšmè. In: Kultūros paminklai, Nr. 13. Vilnius: Savastis, 2008.

28. Rudokas K., Naratyvine kultūros objektu ir instituciju identiteto praturtinimo metodika. Kaunas: Santalka: Filosofija, komunikacija, 2013, 21(2).

29. Panemunès istorija: archeologijos ir meno vadovas, Sud. Rūta Janonienè, Vilnius: VDA, 2006.

30. Vaitkuvienè A., Paveldo industrija Lietuvoje. Lietuvos istorijos studijos 17 (2006 ) 87-96.

31. [interactive] [accessed on 201602 15]

Available from: $<$ http://www.infolex.lt/jurbarkas/Default.aspx?Id=3\&DocId=20077>.

32. Garalienė R., Belazarienè G., Regionio investicinio klimato formavimas. Kauno technologijos universitetas. [interactive] [accessed on 10-05-2016]

Available from: $<$ http://www.lrti.lt/veikla/publikacijos.html $>$.

33. Resolution by the municipality council of Jurbarkas district No. T2-208 of 26 July 2012 „Dèl investicijų pritraukimą į Jurbarko rajono savivaldybę skatinančių priemonių 2012-2020 metų plano patvirtinimo" (On the implementation of the plan of measures for the years 2012-2020 for the promotion of investment attraction into the municipality of Jurbarkas district) [interactive] [accessed on 12-04-2016]

Available from: $<$ http://www.infolex.lt/jurbarkas/Default.aspx?Id=3\&DocId=20077>.

34. Van Der Borg J., Costa P., Gotti G., Tourism in European heritage cities. Annals of Tourism Research 23(2) (1996) 306-321.

35. Lehtimaki M., Kultūros paveldo reikšmè. In: Kultūros paveldas ir turizmas: Galimybès, poveikis, partnerystè ir valdymas. Sud. M. Lehtimaki. 2009.

36. Economic Value of Ireland's Historic Environment. Final Report to the Heritage Council. [interactive] [accessed on 0804 2016] Available from:

$<$ http://www.heritagecouncil.ie/fileadmin/user_upload/Publications/Corporate/Economic_Eval uation of the_Historic_Environment_Ireland.pdf) $>$

37. Kobylinski Z Żigniew, Cultural Heritage Values and Ownership. In: S. Bergerbrant and S. Sabatini (eds.) Counterpoint Essays in Archaeology and Heritage Studies in Honour of Professor Kristian Kristiansen. Oxford, Hadrian Books 2016, p. 719-724. 
38. Ščiglienė V., Almonaitytè-Navickienė V., Čepėnaitė A., Daubarytė K., Kuizinienè I., Anušauskienė L., Déringyte R., Rekašiūte S., Palšyte K., second year MA degree students of UNESCO Culture Management and Cultural Policy Department of Vilnius Academy of Arts. Tour to research site: Analysis of Panemunè Castle case. Social research: interviews with experts. Panemunè Castle, 11-12 December 2015. 